\title{
Hero-cult in Plato's Phaedo, Republic and the Laws
}

\author{
El culto al héroe en Fedón, República y Leyes de Platón \\ Zacharoula Petraki \\ University of Crete, Grecia \\ zpetraki@uoc.gr
}

\begin{abstract}
:
Plato's Phaedo aims to restore the reputation of Socrates by transforming him from a political scapegoat of Athens to a hero of the city who had put him to death. As scholars have shown, the dialogue's heroization of Socrates shares affinities with the religious tradition of the hero cult (see White, 2000; Nagy, 2015). In this article I argue that the conceptualization of the philosopher as a cult hero is developed further in the Republic and the Laws. The Republic presents Socrates as the "oikist" of the ideal polis, who makes religious decisions under the authority of god Apollo. In the same vein, the distinguished classes of the philosopher-rulers in the Republic and of the auditors in the Laws are compared to another group also subsumed under the category of cult-heroes, the victorious Olympic athletes.
\end{abstract}

KeYwORDs: Hero cult, Socrates, Hero, Phaedo, Republic, Laws, Olympic athletes.

\section{Resumen:}

El Fedón de Platón tiene como objetivo restaurar la reputación de Sócrates transformándolo de un chivo expiatorio político de Atenas a un héroe de la misma ciudad que lo había condenado a muerte. Como han demostrado los estudiosos, la heroización de Sócrates en el diálogo comparte afinidades con la tradición religiosa del culto al héroe (ver White, 2000; Nagy, 2015). En este artículo sostengo que la conceptualización del filósofo como héroe de culto se desarrolla más en República y Leyes. La República presenta a Sócrates como el "oikist" de la polis ideal, que toma decisiones religiosas bajo la autoridad del dios Apolo. En el mismo sentido, las clases distinguidas de los filósofos-gobernantes en República y de los auditores en Leyes se comparan con otro grupo también subsumido bajo la categoría de héroes de culto, los atletas olímpicos victoriosos.

Palabras clave: Culto al héroe, Sócrates, Héroe, Fedón , República , Leyes, Atletas olímpicos.

\section{INTRODUCTION}

Plato's Phaedo, written almost two decades after Socrates' death, aims to restore the reputation of Socrates by transforming him from a political scapegoat of Athens to a hero of the city who had put him to death. ${ }^{1}$ As scholars have shown, the heroization of Socrates in the Phaedo shares affinities with the religious tradition of hero cult. In this article I argue that the conceptualization of the philosopher as a cult hero is developed further in the Republic and the Laws. The Republic, in particular, presents Socrates as the "oikist" of the ideal polis, who makes religious decisions under the authority of god Apollo. In the same vein, the distinguished classes of the philosopher-rulers in the Republic and of the auditors in the Laws are compared to another group also subsumed under the category of cult-heroes, the victorious Olympic athletes.

In section 2 ('Hero cult and Plato's Phaedo') I offer a brief account of scholarly views on Plato's adoption of this religious tradition in the Phaedo. In section 3 ('Olympic athletes and Hero cult in the Republic') I examine the creation of the city-guardians and philosophers as "war-athletes" and cult-heroes. In section 4 ('Politics and Hero cult in the Laws') I address the development of this concept in Plato's final work. In section 5 I offer my conclusion. 


\section{Hero-cult and Plato’s Phaedo}

\section{Heroes and hero-cult}

Greek heroes constitute by no means a uniform group. ${ }^{2}$ Instead, the very concept of hero included a great variety of different types exhibiting diverse heroic characteristics. The assorted group includes mythological heroes, ancestors and heroized dead, founding heroes (the archegetai, the oikistai, the eponymoi, the ktistai), the 'healing' heroes, minor local deities, the 'malevolent' and the 'unpleasant' heroes or daimons. ${ }^{3}$ The 'malevolent' heroes, for example, should be propitiated and rest undisturbed. To the group of the 'unpleasant' belonged the majority of the heroized Olympic victors. In their case, heroization has almost a common pattern: a man of exceptional accomplishment is deprived of his rewards (time) and reacts with vehemence. This results in his punishment and death by the citizens, who are themselves punished for their unjust action. In the end, the oracle decrees that they should pay posthumous cultic heroic/divine honours to the deceased. Alongside these categories we also find the 'healing' and 'savior' heroes, who emerge unexpectedly in order to save humans at moments of crisis. Such is, for example, the famous case of Theseus as he was depicted in the Poikile Stoa on Polygnotus' painting of the Battle of Marathon. ${ }^{4}$ According to our sources, the painting showed Athena, Heracles, Theseus, and Echetlaios defending Marathon and its people. In the painting Theseus, the famous hero par excellence of Athens, is shown rising from the Attic earth, an allusion to his autochthony and to the transferal of his bones by Cimon to Athens. ${ }^{5}$ In this respect, the supernatural helpers share notable similarities with the dead, who may also be invoked from Hades in order to offer their help to the living, as is the case with the ghost of Darius in Aeschylus' Persians. Finally, another group includes the 'self-sacrificing' heroes and heroines, youths, mythical kings and generals, who die to save their country. Their sacrifice shares affinities with the scapegoat rituals, whereby the city sacrificed marginalized persons, criminals, or slaves, to remove pollution and appease the wrath of the gods.

While the exact origin of hero-cult in Ancient Greece has become a central feature of scholarly debate, in recent years it is generally accepted that the "conceptualization of the category ippw" as someone who receives sacrificial rituals materialized only in the later six century. ${ }^{6}$ In the Archaic and Classical period recently deceased persons were heroized and received from the community posthumous sacrificial honours and cultic worship (thysiai and enagismata): ${ }^{7}$ these were city founders (the oikists), Olympic athletes, and outstanding benefactors, such as, for example, the famous Tyrannicides of Athens. ${ }^{8}$ The heroization of 'real' as opposed to mythical persons was significantly enhanced in the fifth-century BCE, when the war dead were also awarded heroic honours by the polis. ${ }^{9}$ The extent to which these took place as part of an official cultic 'heroization' has been fiercely debated; and yet, the truth remains that the Classical Athenians "heroized their benefactors as best as the could". ${ }^{10}$

Like gods, heroes were powerful beings who could use their powers to help or punish humans. ${ }^{11} \mathrm{~A}$ characteristic example is Sophocles' Oedipus in the Oedipus at Colonus, who as a hero of Athens adopts certain features of the Eumenides and protects the city of Athens against its enemies. ${ }^{12}$ Unlike gods, however, heroes can be 'real life' people whose abode lies within the depths of earth. From their tomb, be it secret (as in the case of Oedipus at Colonus) or public, they distributed both blessings and retribution to humans. ${ }^{13}$ The benefits for the individual and the community at large from paying honor to a hero are numerous and diverse. Like the gods, heroes can restore one's health in a mysterious and daimonic manner. They can help humans in seafaring and save them from shipwreck. They may assist them in war, famine, and in natural disasters. In return, both individuals and the community perform annual sacrifices that seek to secure their continued protection and benefaction. 


\section{Socrates as hero in the Phaedo}

Several studies have shown that Plato's description of Socrates' final moments in the Athenian prison paints the portrait of a philosophical hero whose calmness in the face of death outshines the manliness of traditional mythical heroes. ${ }^{14}$ Allusions to Socrates' heroic stance are variously scattered throughout the dialogue. As Phaedo sets the scene inside the prison, Socrates is implicitly likened to the mythical king Theseus, the great savior and cult hero of Athens. Phaedo explains that the Athenian festivals in honor of Theseus and Apollo gained the imprisoned Socrates a brief lease of life (58a-c). The remark seems to be hinting, just as Theseus in olden times set sail and led the "twice seven" youths and maidens to Crete, and "saved them and was himself saved," so does the traditional Athenian theoria to Delos give Socrates the opportunity to present on the day of his death his own "second journey" to philosophy, the Platonic Ideas, and to "save" another group of men, his friends who are attending him in prison. ${ }^{15}$ In the same vein, Phaedo draws attention to Socrates' exclusive relation to god Apollo. The dialogue presents Socrates as a quasi-seer, namely the "fellow-servant

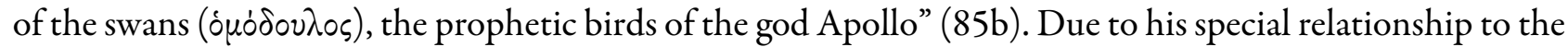

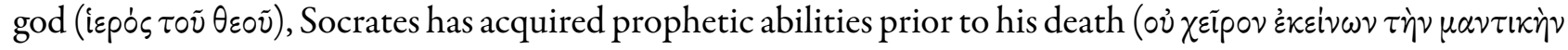
$\ddot{\varepsilon} \chi \varepsilon \mid \nu \pi \alpha \rho \dot{\alpha} \tau \circ \tilde{v} \delta \varepsilon \sigma \pi \dot{\jmath} \tau 0 \nu)$, allowing him to describe the fate of the soul after death.

An explicit correlation, however, between Socrates and a hero is made at the end of the dialogue (115a), when Socrates declares that it is time to drink the hemlock. This short phrase makes a clear reference to ancient Greek tragedy and invites us to compare the dying philosopher with a tragic hero:

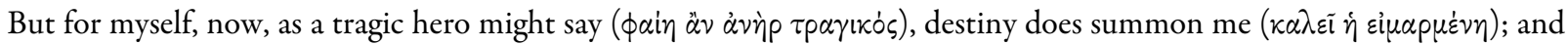

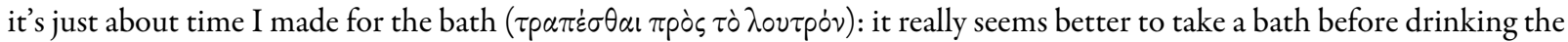
poison, and not give the women the trouble of washing a dead body.

Socrates' enigmatic words have been the focus of much scholarly attention. Is this passing remark an allusion to a specific tragic hero? Of particular importance here is the detail that Socrates himself gives us, when he does not compare himself to any hero but to one whose fate calls him to his death and who himself performs the ritual for the care of the body of the dead that is customary and unviolated, before and not after his death. Scholars interpreting this scene turn to the surviving tragedies that represent a hero with these characteristics. The corpus includes two tragedies who fulfill these preconditions: Euripides' Alcestis, and Sophocles' Oedipus at Colonus.

The three works share the following common characteristics: 1) a "divine" voice calls the heroes to death; ${ }^{16}$ 2) all three carry out themselves alive the customary ritual of washing the dead body; ${ }^{17} 3$ ) the death of all three heroes is termed excellent and "admirable"; 18 4) the journey towards death is marked by matchless strength and remarkable courage; ${ }^{19}$ and 5) their unique death blurs the "clear" boundaries between life and death, ${ }^{20}$ thereby defeating, mutatis mutandis, conventional death. In Phaedo's case, the view of philosophy as the "study of death" ( $\mu \varepsilon \lambda \dot{\varepsilon} \tau \eta \theta \alpha \nu \dot{\alpha} \tau O v)$ leads to the redefinition of the meaning of human life.

In a previous work I have argued in favor of the view that the Socratic comment at 115a forms part of the wider theme of Socrates' heroization in the Phaedo, and that it may function as an interpretive springboard for a comparative consideration of the Platonic dialogue and the tragedy of Oedipus at Colonus which launches the hero-cult of Oedipus as a protector of Athens. ${ }^{21}$ My proposed interpretation took as its starting-point Stephen White's study "Socrates at Colonus: A Hero for the Academy," published in a collective volume on Socrates. White persuasively argues that Plato, imitating Sophocles and the tragedians,

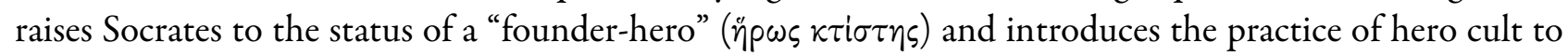
the Academy in his honor: a) an annual ceremony including the sacrificial ritual, b) the celebration of the philosopher's memory, and c) the payment of honors at the hero's tomb. ${ }^{22}$ By comparing Plato's praise of Socrates with the establishment of the cult of Oedipus as a hero of Athens, as this is dramatized in Oedipus 
at Colonus, White identifies at key points in the Phaedo hints at the cult of Socrates as a hero at the Academy and argues, convincingly in my view, that the Platonic philosophers' practice of holding annual festivals in Plato and Socrates' memory did not begin at the Platonic Academy with Plato's nephew Speusippus and his Perideipnon .Funeral Banquet), but was inaugurated earlier by Plato himself with the work Phaedo. ${ }^{23}$

Taking its cue from White's interpretation, my comparison of the two works focused on the way in which Plato and Sophocles treat the body of the two heroes as the seat of otherwordly forces and subvert the convention of its burial in the context of their heroization. In the $O C$, Oedipus' presence in the grove of the Eumenides is crucial to the establishment of his cult in Athens. ${ }^{24}$ His gradual ontological transition to a heroic status is dramatized by making him resemble on stage the invisible chthonic deities. ${ }^{25}$ The polluted body of Oedipus becomes a projection of Eumenides' power as the old man acquires some of their divine authority: as a hero he will be well disposed towards the friends who will tend his grave and a vengeful punisher of his enemies. ${ }^{26}$ The grave -a blessing for Athens- will remain invisible to everyone except Theseus.

The Phaedo holds a special position in the Platonic corpus for its ontological debasement of the human body to the level of the imperfect sensible world. ${ }^{27}$ In this dialogue the body in general is depicted as the polluted cover of the immortal soul, but the body of Socrates seems to be set apart from those of other mortals due to the singular influence of the Platonic Ideas on his soul. Although the dialogue opens with Socrates imprisoned in the Athenian jail and his companions free, as the narrative unfolds, this motif is gradually reversed. The Socratic body, with its plain description and controlled reaction in the face of death, is only apparently trapped in prison; in fact, the body operates as a depiction of Socrates' soul, which is the freest of all because it has managed to cast off the ties "binding" it to the sensible world. Thus the text implies that the true prisoners are the mortals whom Socrates leaves behind in the sensible world, those who are "full of body." 28

Comparably, both works approach in an idiosyncratic manner the tombs of the two men. Significant archaeological findings, such as hero-tombs near the gates and walls of cities, demonstrate that in Greece the sacred protection of cities was entrusted to guardian heroes. These need not necessarily be native, since foreigners could also change allegiance once they found burial in the new polis. Because heroes were insolubly bound with the place they protected, possessing their remnants was indispensable to laying claim to their posthumous power. ${ }^{29}$ This is not the case, however, with Oedipus, whose body miraculously disappears into the bowels of the earth of Attica. ${ }^{30}$ His worship in Athens was uncustomary in this respect because the tragedy makes no reference to a funerary mnema or to an heroon. The place which will receive the cultic honors is secret to everyone but Theseus. Hence, Athens will enjoy his guardianship but without having access to his remnants. Oedipus' heroization is realized via the wondrous disappearance of his polluted body.

Mutatis mutandis, Plato in the Phaedo makes no reference to Socrates' tomb and silences the possibility of linking any future honors with the care of his tomb. ${ }^{31}$ Instead, Plato presents Socrates as a hero of philosophy, whose power lies in the qualities of his soul and not in the extraordinary capacities of his body. ${ }^{32}$ Thus the dialogue focuses on the significance of the physical body as the symbolic 'tomb' of the immortal soul and not on the posthumous care of the conventional tomb of the beloved philosopher as the ultimate recipient of heroic honors. ${ }^{33}$ The rejection of the importance of the body of the hero in the Phaedo goes hand in hand with the rejection of the significance of a conventional burial. According to custom, the body of the dead is prepared and bathed soon after death. Then follows the prothesis for viewing and mourning, the procession (ekphora), and the pouring of libations (choai). ${ }^{34}$ Although the Phaedo closes with a memorable detailed description of the dying Socratic body, it makes no mention of the funerary rites following the death of Socrates. On the contrary, like Sophocles, Plato reverses the established treatment of the dead body by showing Socrates talking to Crito about the impending burial of his body in a detached and playful manner 
( $\gamma \varepsilon \lambda \dot{\alpha} \sigma \alpha \varsigma \delta \dot{\varepsilon} \ddot{\alpha} \mu \alpha \dot{\eta} \sigma \dot{\chi} \chi \tilde{\eta}, 115 \mathrm{c} 3),{ }^{35}$ and carrying out, while yet alive, the chief stages of burial, the washing (115a) and laying out of the corpse ( $\kappa \alpha \tau \varepsilon \kappa \lambda i \nu \eta \cup \pi \tau \tau, \varsigma, 117 \mathrm{e} 3$ ), the pouring of the libations and the sacrifice.

Scholars have interpreted Socrates' reversal of the rites as an allusion to the symbolic identification of the living body with a tomb, implying that the non-philosophical living are essentially dead. In my comparative reading of the two works I took a difference stance. Key to my interpretation is the view that the deaths of Oedipus and Socrates do not take place at the end but have, in a way, already taken place since the beginning. The heroes' living presence is an ingenious literary mantle, as it were, of which they are gradually divested, displaying to the audience aspects of their different ontological state. The proposed interpretation involves the depiction of the two heroes as a sort of "living dead men," with the final death scenes signifying the climax and completion of a metamorphosis set in motion long before. Consequently, the two works do not simply narrate the deaths of the main characters as being the prerequisite threshold to heroization, but dramatize the shift in their ontological statues before their conventional death in front of the audience's eyes. Oedipus and Socrates, in other words, "are already the heroes they will 'become' after their death." ${ }^{36}$ Focusing on Socrates, the interpretation of his persona in the Phaedo as a sort of living dead man, introducing the theory of Forms to his friends, is supported by the eschatological myth of the dialogue, according to which those who have "successfully purified their soul through philosophy live without a body for the rest of time." 37 Based on this interpretation, the Socratic persona in the Phaedo "dramatizes" in the dialogue what is described in the eschatological myth concerning the transmigration of philosophical souls. According to Phaedo 114c-d, only the philosopher can successfully overcome the physicality of repeated reincarnations and preserve his soul without a body forever. This liberation from physicality is a consequence of the crucial influence of the study of the Ideas on the soul.

As the dialogue blurs the clear-cut boundaries between life and death, one is even allowed to raise the question whether the Socrates of the Phaedo, whose detachment from the material world and from his own body is variously emphasized in the dialogue, is the 'eidolon', as it were, of an already 'disincarnate' hero, who due to the practice of philosophy has escaped the vicious circle of reincarnation, and has come to 'save' the living by revealing to them the nature of the Forms and the true fate of the human soul. On this interpretation, the dialogue points towards common beliefs according to which heroes return to the world of the living in order to help them in times of crisis. ${ }^{38}$ Hence, if, as White has argued, the Phaedo includes hints to the cult of Socrates as a hero of the Academy, then Plato has adapted this religious custom to serve his own philosophical agenda. Socrates, who was admittedly unjustly tried and condemned, ${ }^{39}$ becomes the hero par excellence of philosophy; the "pariah" and the political scapegoat, who some years before the dialogue's composition was expelled from the "body" politic of Athens, returns as a daimon and as the god-sent seer of Apollo. However, unlike Theseus, as portrayed in the painting of the Poikile Stoa, Socrates does not 'rise' from the ground in order to help his fellow Athenians. Unlike Oedipus in the Oedipus at Colonus, he does not 'return' to the bowels of Athenian earth as part of his heroization. Instead, his heroic status stems from his close association with the Platonic Forms and the world of the intellect. ${ }^{40}$

\section{Olympic athletes and Hero cult in the Republic}

If in the Phaedo the various threads that make up the heroization of Socrates are interwoven in a less conspicuous manner, this is not the case with the Republic where the conceptualization of the guardians and the philosopher-rulers as 'heroes' of the ideal city is explicitly stated in the text. The Republic adopts the notion of heroic honours to the guardians but focuses on a specific group subsumed under the category of heroes, the victorious Olympic athletes. Time and again, Socrates compares the life of the city guardians with the status of Olympic victors in terms of civic/ethical excellence (arete) and happiness (eudaimonia). Nonetheless, the correlation does not result in the unquestionable exaltation of athletic achievement. 
Instead, Plato views the cultural dromena of his own time with a critical eye and modifies them so as to serve his own philosophic target. In what follows I will delve into the comparison of the guardians and the philosophers with Olympic victors and address its relation to the award of hero-cult to these two classes of the ideal polis.

Let us start with those passages in the Republic where comparisons with Olympic victory are drawn. These appear in Books 5 and 7. In Book 5, Socrates employs the comparison with the Olympic victors in the context of his description of the ideal city. In $465 \mathrm{~d}-\mathrm{e}$, Socrates asserts that the life of the auxiliaries-guardians of the ideal city surpasses in happiness the life of the Olympic victors. As Socrates says, his Guardians will experience a state of "continuous victory", which is far more beautiful and complete than the one enjoyed by the victors of the Olympic games:

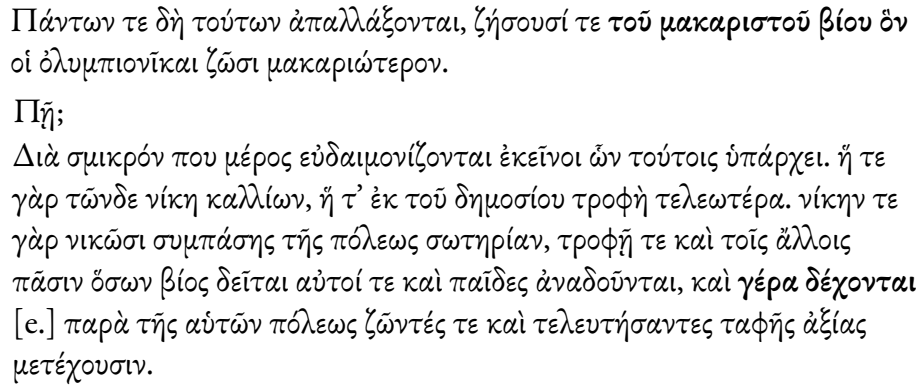

They'll be free of all these, and they'll live a life more blessedly happy than that of the victors in the Olympian games.

How?

The Olympian victors are considered happy on account of only a small part of what is available to our guardians, for the guardians' victory is even greater, and their upkeep from public funds more complete. The victory they gain is the preservation of the whole city, and the crown of victory that they and their children receive is their upkeep and all the necessities of life. They receive rewards from their own city while they live, and at their death they're given a worthy burial. ${ }^{41}$

The supreme status of the Olympic victors constitutes the measure against which Plato assesses the life of the people who will live in accordance with the rule of reason. Nonetheless, in the comparison of his guardians with the Olympic victors, the former come off better. Plato may have included gymnastics as an integral part of the educational curriculum of the Republic, but he does not consider the apogee of athletic excellence as equal to a life of philosophy. ${ }^{42}$

In Book 7. 540a-c, Socrates concludes the description of the philosopher-rulers and their education. After

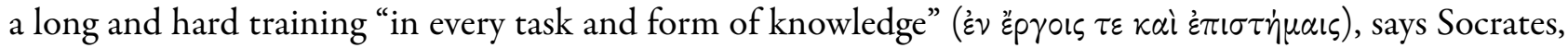
the philosophers will turn the eye of their soul to the Form of Good and use it as a "pattern" ( $\pi \alpha p \alpha \delta \varepsilon i \gamma \mu \alpha \tau$ เ

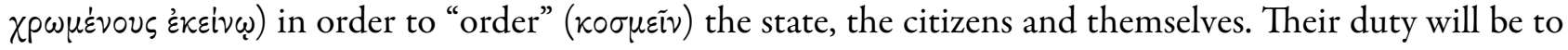
prepare the next generation to take over the government of the city when they die and after their death, says Socrates, they will depart not for Hades but for the Islands of the Blessed ( The duty of the polis, on the other hand, is to offer them supreme honors after they die (540b7-c2):

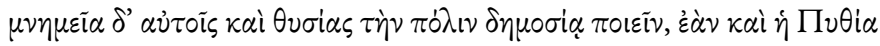

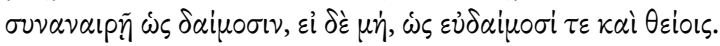

And, if Pythia agrees, the city will publicly establish memorials and sacrifices to him as a daimon, but if not, then as a happy and divine human being.

The proposal that the philosophers-rulers should receive after death the ultimate civic honors, namely monuments and sacrifices, crowns Socrates' long and laborious argumentation that they constitute the most important class for the creation and the continuance of the kallipolis. ${ }^{43}$ This proposal is heralded in a comparable remark made earlier in relation to the city guardians. After Socrates' observation in Book 5 (465d-e) that the guardians surpass in virtue and happiness the Olympic victors, in $468 \mathrm{c}-469 \mathrm{~b}$, Socrates goes on to compare the honors $(\tau \mu \tilde{\alpha} \nu)$ accorded to the young guardians who excel in their service to the 
polis to the Homeric and Hesiodic heroes. The young guardians are firstly compared in terms of valor to Aias and are accorded similar heroic honors: hymns and sacrifices, "seats of honor, meats, and well-filled

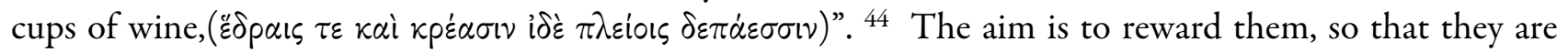
trained to protect the city as best as possible. Similarly, those guardians who find distinguished deaths in

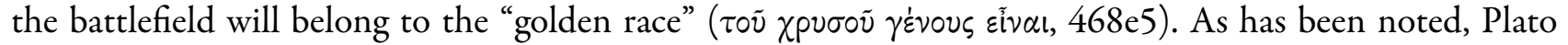
makes an allusion here to the first of the five Hesiodic races, which culminates with the citation of two lines from the Works and Days (1. 122):

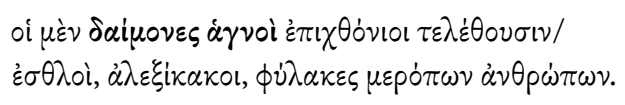

These exceptional people, the city-guardians, Socrates goes on, will have attained the ultimate status of daimonic and godlike people and for this they must receive the corresponding rewards: Apollo will "be

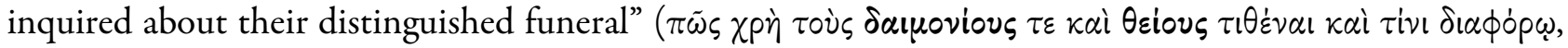
469a7-8). For the remainder of time,

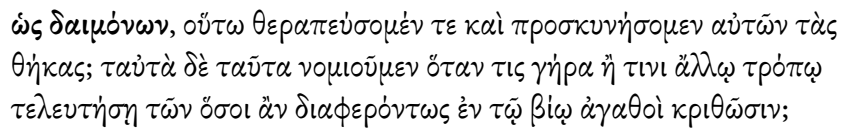

We'll care for their graves and worship at them as we would at those of daimons. And we'll follow the same rites for anyone we judge to have lived an outstandingly good life, whether he died of old age or in some other way (469a7-468b3).

In these passages Plato makes Socrates draw from Hesiodic poetry and from Greek religion in order to shape the identity of the two best classes of kallipolis. ${ }^{45}$ The extract cited above from Book 5 draws on the 'Noble Lie', introduced at the end of Book 3, according to which the citizens of the ideal polis will fall into three categories depending on the metal that was inculcated in their souls when they were molded by mother earth. ${ }^{46}$ The philosophers-rulers are identified with the golden race, the guardian-auxiliaries with the silver, and the craftsmen with the iron. ${ }^{47}$ Socrates focuses here on a very specific aspect of the Hesiodic golden race, namely the belief that the best genos of men after death continue to wander on earth (epichthonioi) as sacred daimones, helpers, and guardians of the living. Socrates' belief that the philosopher-guardians and the guardian-auxiliaries constitute an ontologically elevated version of human beings is inextricably combined with his recommendation that when deceased they should receive the customary cultic heroic honors: monuments (possibly comprising statues, bomoi, or heroa) and annual sacrifices. The basis for the proposal that they are heroized after death is their confirmed civic excellence. Throughout the discussion Socrates is adamant that the guardian-philosophers and the guardian-auxiliaries should devote their entire lives to the good of the polis. ${ }^{48}$ The polis in return should honor them for their service with the ultimate

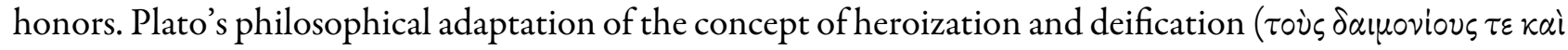
$\theta \varepsilon i o v \varsigma, \dot{\omega} \varsigma \delta \alpha \mu \dot{\delta} v \omega \nu, \dot{\omega} \varsigma \delta \alpha i \mu \sigma \sigma \nu)$ for the city guardians and philosophers is both religious and political in its derivation. As has been argued by historians and archaeologists, hero-cults were integral to the creation of the identity of the polis: the hero "stands as a focal figure for the neonate socio-political community, and the centrality which he enjoys within the 'imaginary city' is physically symbolized by his establishment (either in a tomb or in a heroon) within the agora." ${ }^{49}$ Once a hero's worship was ritually established, the hero remained firmly incorporated within the ideological framework of the polis. In essence, the city was its local hero. On the basis of the above, we are now in a better position to understand the political ramifications of Socrates' religious recommendations in the passages cited above. The city guardians were not merely the founders of the kallipolis but they also were a continuous form of inspiration for the future generations of guardians and philosophers. Their heroization and cultic rewards secured the very continuation of the polis through the creation of a chain of philosophers who would share common ethical characteristics.

But is Plato's adoption of the concept of guardian heroization limited only to the allusions to the Hesiodic 'golden race'? How are we to understand Socrates' comparison between philosophers and Olympic victors in 
the passages cited above? And what is the role that Plato assigns to Socrates against this background? Socrates' comparison between guardians and Olympic victors should not be interpreted as a mere passing remark to the uncontested aristeia and eudaimonia enjoyed by the former but as part of the broader conceptualization of the guardians-philosophers as a cult-heroes. As scholars have observed, athletic victory transformed the mortal body, the very "instrument of victory" and the instantiation of the celebrated and wondrous arete. ${ }^{50}$ The view of the athlete's body as the seat of god-given powers (aretai) in many cases went hand in hand with the heroization and veneration of the victorious athletes as cult heroes. ${ }^{51}$ In fact, we have information about athletes who emulated mythical heroes and received hero worship in their cities having thus ascended to an elevated ontological level. ${ }^{52}$ Euthymos of Lokroi was credited with saving the people of Temesa from the vengeful ghost of the so-called Hero and venerated as a hero. ${ }^{53}$ The Spartans worshipped the wrestler Hipposthenes who won six Olympic crowns in the seventh century BC. ${ }^{54}$ The six-time Olympic champion Milo of Croton impersonated Heracles in his victorious effort to lead his fellow countrymen against Sybaris. ${ }^{55}$ The pankratiast Polydamas (Olympic victor in 408 BC) modeled his behaviour a er Heracles and was worshipped a er his death for exhibiting supernatural healing powers. ${ }^{56}$ Thus, Plato's conception of kallipolis' best class is not founded exclusively on the Hesiodic metallic races but is the product of an ingenuous amalgamation of Hesiod's golden genos with the extraordinary nature of the victorious Olympic athletes. In fact, at the end of Book Three, Socrates

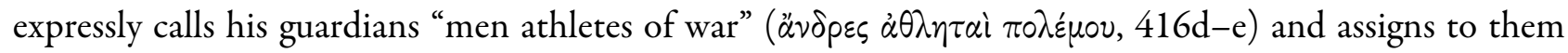
the two key virtues of sophrosyne and andreia. ${ }^{57}$ Hence, both types of heroes have as common denominator, the posthumous attainment of a daimonic status.

Let us now turn to one last question regarding Socrates' part in this fusion of religious ideas and cultic practices in the Republic. Plato makes Socrates address himself his own status in this political scheme. In Republic Book 3 Socrates embarks on the long criticism of the representation of gods and heroes in poetry. Socrates announces that he and his interlocutors can control the poetic compositions on account of their role as the "founders" of the ideal city. It is the duty of the oikists, says Socrates, to know the patterns according to which the poets must compose their poems for the new city. ${ }^{58}$ This passing metaphor of Socrates as an oikist of kallipolis takes on a different meaning when seen as part of the thick network of language and imagery related to hero-cult in this work. Traditionally, the founder of a new colony was the first person to receive heroic cult honors after his death. The cult was located at his tomb at the agora and took the form of annual commemoration. ${ }^{59}$ According to Malkin,

In the subsequent history of each colony the memory of its foundation continued to play a central role through the heroic cult accorded to the deceased founder [...] being, as it were, the first cult which was the colony's own, not having been imported from its mother-city [...] it made concrete and perpetual the possession of the colony, it accorded the colonists the heroic protection of their own guardian hero (polissouchos) and provided each colony with its first historic symbol $a b$ urbe condita. ${ }^{60}$

Hence, although not explicitly stated in the dialogue, we may infer that Plato's declaration of Socrates as the oikist of kallipolis sets a specific ideological tone. Socrates, in other words, is assigned the double role of heros ktistes of the Academy (as White argues) and of the oikist of Plato's ideal polis and he then 'passes on' his heroic status to the next generation of city guardians and philosophers. At the same time, the several references to god Apollo of Delphi also take on a new significance, since, traditionally, the oracle played an integral role in foundation of a new city with the oikist being the crucial religious intermediate between the polis and god Apollo. ${ }^{61}$ 


\section{Politics and Hero cult in the Laws}

Plato's amalgamation of religion and philosophy, which has started in the Phaedo and in the Republic, continues in his final work, the Laws. The Laws is a conversation about legislation among three old men: an anonymous Athenian, called the 'Stranger', Megillus of Sparta and Clinias, citizen of the Lacedaemonian colony of Knossos. In the course of the discussion, Clinias reveals to his interlocutors that he will soon participate in the formulation of the laws of a new Cretan colony, the city of Magnesia. Compared to the theoretical city of the Republic, the city of Magnesia presents a different socio-political structure. The citizens are all landowners of small lots, who have their own private life and families. In political life, the leadership of the philosophers-kings has given way to the division of political power among various sets of magistrates. Nonetheless, as has been observed in the scholarship, philosophy continues to rule in Magnesia, since the law is intended to represent the rule of Reason on earth. In his last work Plato modifies certain views about the organization of a sound society, but he does not change his aim: the imagined colony of Magnesia must be harmoniously unified, since for the Athenian Stranger too, the best society is the one in which the citizens behave unanimously, as though they were a single person. ${ }^{62}$

In the Laws, to live a virtuous life is to conform to the laws and the intentions of the lawgiver. ${ }^{63}$ In addition, according to the Athenian Stranger, every citizen should be simultaneously a performer of virtuous life and a critic of the performance of virtue of his or her fellow-citizen. From this point of view, Magnesia is a very agonistic city indeed. ${ }^{64}$ Nonetheless, contrary to the Republic, Plato in the Laws is very selective as to who should be accorded the megistai timai in Magnesia. In 945b the Athenian Stranger announces that only the supreme class of the auditors, who supervise the city magistrates and the distribution of praise and blame in the city may receive cultic honours. Like the philosopher-kings, the auditors are the only ones

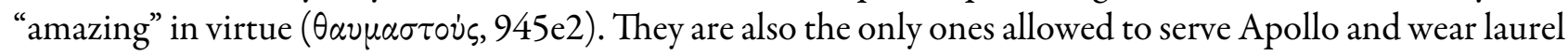
wreaths while alive. In their funerals they are not mourned with dirges but they are celebrated with hymns and eulogized for their exceptional aristeia. They receive annual celebrations in the form of musical and athletic contests, and perhaps most importantly, their tombs and surrounding grove become monuments of uncontested excellence as they are dedicated to the city gods. ${ }^{65}$

\section{Conclusion: Heroization, Deification, Reincarnation}

In this article I have argued that Plato's adoption of the concept of hero-cult in the Phaedo, the Republic, and the Laws crowns his conviction that philosophers constitute the most important class in the creation of a sound society. Hence, Plato resorts to traditional religious beliefs and to the ideology of hero-cults but only in order to give them a new philosophical twist. Crucial in this direction is the adoption of the belief of one's alleged return to the world of the living as a benevolent daimon. The concept of a daimonic supernatural being, which, as we saw, is often found in the stories of cult heroes, has been interpreted in the scholarly literature as a development of the famous Socratic daimonion. ${ }^{66}$ However, the Platonic view of reincarnation and deification brings a whole new aspect to the deceased philosophers as benevolent daimons. According to Phaedo's view on reincarnation, philosophers are the only humans who will escape the vicious circle of metempsychosis. ${ }^{67}$ This may be combined with Socrates' views in the Republic and the Phaedrus that the practice of philosophy transforms your soul and can make you divine. ${ }^{68}$ The notion of Platonic philosophers as cult-heroes is an ingenious encapsulation and amalgamation of both these fundamental philosophic beliefs. 


\section{REFERENCES}

Adam. J. (Ed.) (1902). The Republic of Plato. Cambridge: Cambridge University Press.

Ahrensdorf, P. J. (1995). The Death of Socrates and the Life of Philosophy. Albany, NY: State University of New York Press.

Antonaccio, C. M. (1994). Contesting the past. hero cult, tomb cult, and epic in early Greece. AJA, 98, 389-410.

Antonaccio, C. (1999). Colonization and the origins of Hero Cult. In R. Hagg, R. (Ed.), Ancient Greek Hero Cult, 109-121. Stockholm: Svenska Institutet i Athen.

Arieti, J. (1986). A Dramatic Interpretation of Plato's “Phaedo". Illinois Classical Studies, 11 (1/2), 129-142.

Azoulay, V. (2014). Les Tyrannicides d'Athenes: vie et mort de deux statues. L'Univers historique. Paris: Editions Seuil.

Barron, J. P. (1999). Pythagoras' Euthymos: Some Thoughts on Early Classical Portraits. In R. Mellor and L. Tritle (Eds.), Text and Tradition: Studies in Greek History and Historiography in Honor of Mortimer Chambers (pp. 37-59). Claremont, CA: Regina Books.

Blundell, M. W. (1989). Helping Friends and Harming Enemies. A Study in Sophocles and Greek Ethics. Cambridge: Cambridge University Press.

Bobonich, Ch. and Meadows, K. (Winter 2020 Edition). Plato on utopia. The Stanford Encyclopedia of Philosophy. Edward N. Zalta (Ed.), URL <https://plato.stanford.edu/archives/win2020/entries/plato-utopia/>;.

Boedeker, D. (1995). Simonides on Plataea: Narrative Elegy, Mythodic History, Zeitschrift für Papyrologie und Epigraphik, 107, 217-229.

Burnet John (Ed.). (1903). Platonis Opera, Vol. IV. Oxford Classical Text. Oxford: Oxford University Press.

Burnet, J. (Ed.). (1911/1977). Plato's Phaedo. Edited with Introduction and Notes. Oxford: Oxford University Press.

Bremmer, J. N. (2007). The Rise of the Hero Cult and the New Simonides. Zeitschrift für Papyrologie und Epigraphik, $158,15-26$.

Brown, A. L. (1984). Eumenides in Greek Tragedy. CQ, 34, 260-281.

Calame, C. (1998). Mort héroique et culte à mystère dans l' Oedipe à Colone de Sophocle. In F. Graf (Ed.), Ansichten griechischer Rituale, Geburtstags-Symposium für Walter Burkert (326-356). Stuttgart and Leipzig.

Currie, B. (2002). Euthymos of Locri: A Case of Study in Heroization in the Classical Period.JHS, 122, 22-44.

Currie, B. (2005). Pindar and the Cult of Heroes. Oxford: Oxford University Press.

Day, J. W. (2010). Archaic Greek Epigram and Dedication: Representation and Reperformance. Cambridge: Cambridge University Press.

Edmunds, L. (1981). The Cults and the Legend of Oedipus. HSCPh, 85, 221-38.

Edmunds, L. (1996). Theatrical Space and Historical Place in Sophocles' Oedipus at Colonus. Rowman and Littlefield Publishers.

Eisner, R. (1982). Socrates as Hero. Philosophy and Literature, 6, 106-18.

Ekroth Gunnel (2002). The Sacrificial Rituals of Greek Hero-Cults in the Archaic to the Early Hellenistic Period. Liege: Presses universitaires de Liege.

Ekroth Gunnel (2007). Heroes and Hero-Cults. In D. Ogden (Ed.), A Companion to Greek Religion, Blackwell companions to the ancient world (pp. 100-114). Malden; Oxford: Wiley-Blackwell.

Farnell, L. R (1921). Greek Hero Cults and Ideas of Immortality. Oxford: Oxford University Press.

Felton, D. (1999). Haunted Greece and Rome. Austin: University of Texas Press.

Fontenrose, J. (1968). The Hero as Athlete. CSCA, 1, 73-104.

Garland, R. (1985). The Greek Way of Death. Ithaca: New York.

Gebhard, E. R. and Dickie, M. W. (1999). Melikertes-Palaimon, hero of the Isthmian Games. In R. Hagg(Ed.), Ancient Greek Hero Cult (pp. 159-165). Stockholm: Svenska Institutet i Athen. 
Hall, J. M. (1999). Beyond the Polis. The Multilocality of Heroes. In R. Hagg, (Ed.), Ancient Greek Hero Cult (pp. 49-59). Stockholm: Svenska Institutet i Athen.

Hagg, R. (Ed.). (1999). Ancient Greek Hero Cult. Stockholm: Svenska Institutet i Athen.

Henrichs, A. (1983). The "Sobriety" of Oedipus: Sophocles OC 100 Misunderstood. HSCP, 87, 87-100.

Johnston, S. Iles. (1999). Restless Dead: Encounters Between the Living and the Dead in Ancient Greece. Berkeley: Los Angeles.

Kearns, E. (1989). The Heroes of Attica. BICS Supplement 57. London: Institute of Classical Studies.

Keesling, C. (2017). Early Greek Portraiture: Monuments and Histories. Cambridge: Cambridge University Press.

Knox, B. (1964). The Heroic Temper. Berkeley and Los Angeles: University of California Press.

Kron, U. (1999). Patriotic Heroes. In R. Hagg (Ed.), Ancient Greek Hero Cult (pp. 61-83). Stockholm: Svenska Institutet i Athen.

Kurke, L. (1991). The Traffic in Praise: Pindar and the Poetics of Social Economy. Ithaca, NY: Cornell University

Press. Kurke, L. (1992). The Politics of åßpoớrn in Archaic Greece. ClAnt, 11, 111-112.

Kurke, L. (1993). The Economy of Kudos. In C. Dougherty and L. Kurke (Eds.), Cultural Poetics in Archaic Greece (pp. 131-163). Cambridge: Cambridge University Press.

Lampert, L. (2021). How Socrates Became Socrates: A Study of Plato's "Phaedo," "Parmenides," and "Symposium". Chicago: University of Chicago Press.

Liebert, R. S. (2020). Mourning Socrates: Plato's Phaedo and Tragic Philosophy. Classical Philology, 115 (3), 442-466.

Linforth, I. M. (1951). Religion and Drama in "Oedipus at Colonus". Berkeley, Los Angeles, CA: University of California Press.

Loraux, N. (1981). L'invention d'Athènes. Paris: Mouton/École des Hautes Études en Sciences Sociales.

Loraux, N. (1995/2014). The Experience of Tiresias. Princeton: Princeton University Press.

Lunt, David J. (2009). The Heroic Athlete in Ancient Greece. Journal of Sport History, 36, 375-92.

Malkin, I. (1987). Religion and Greek Colonization. Leiden: Brill.

Markantonatos, A. (2007). Oedipus at Colonus. Berlin, New York: Walter de Gruyter.

McCauley, B. (1999). Heroes and Power: The Politics of Bone Transferal. In R. Hagg (Ed.), Ancient Greek Hero Cult (pp. 85-98). Stockholm: Svenska Institutet i Athen.

Méautis, G. (1940). L'Oedipe à Colone et le culte des héros. Recueil de la Faculté des Lettres de Neuchâtel 19. Neuchâtel.

Mikalson, J. D. (2010). Greek Popular Religion in Greek Philosophy. Oxford: Oxford University Press.

Morgan K. A. (2010). The voice of Authority: Divination and Plato's Phaedo. CQ, 60, 63-81.

Morgan, K. (2013). Praise and Performance in Plato's Laws. In A-E, Peponi (Ed.), Performance and Culture in Plato's Laws (pp. 265-294). Cambridge: Cambridge University Press.

Nagy, G. (1979). The Best of the Achaeans: concepts of the hero in Archaic Greek poetry. Baltimore: The Johns Hopkins University Press.

Nagy, G. (2015). On Traces of Hero Cults for Socrates and Plato. Retrieved from http://classical-inquiries.chs.har vard.edu

Nightingale, A. W. (2021). Philosophy and Religion in Plato's Dialogues. Cambridge: Cambridge University Press.

Notomi, N. (2011). Socrates in the Phaedo. In G. Boys-Stones, D. El Murr, and C. Gill (Eds.), The Platonic Art of Philosophy (pp. 51-69). Cambridge: Cambridge University Press.

Ogden, D. (2002). Magic, Witchcraft and Ghosts in the Greek and Roman Worlds. Oxford: Oxford University Press.

Parker, R. (1996). Athenian Religion: A History. Oxford: Oxford University Press.

Petraki, Z. (2015-16). The body of the hero: death and heroization in Sophocles' Oedipus at Colonus and Plato's Phaedo. Ariadne, 22, 127-162.

Podlecki, A. (1971). Cimon, Skyros and 'Theseus' Bones'. JHS, 91, 141-143.

Ranasinghe, N. (2000). The Soul of Socrates. Cornell University Press. 
Seaford, R. (1994). Reciprocity and Ritual: Homer and tragedy in the developing city-state. Oxford: Oxford University Press.

Smith, R. R. R. (2007). Pindar, Athletes and the Early Greek Statue Habit. In S. Hornblower and C. Morgan (Eds.), Pindar's Poetry, Patrons and Festivals: From Archaic Greece to the Roman Empire (pp. 83-139). Oxford: Oxford University Press.

Steiner, D.T. (1998). Moving Images: Fifth-Century Victory Monuments and the Athlete's Allure. ClAnt, 17, 123150.

Steiner, D.T. (2001). Images in Mind: Statues in Archaic and Classical Greek Literature and Thought. Princeton: Princeton University Press.

Tilg, S. (2004). Die Symbolik chthonischer Gotter in Sophokles "Oedipus auf Kolonos", Mnemosyne, 57, 407-420.

Trépanier, S. (2017). From Hades to the Stars: Empedocles on the Cosmic Habitats of Soul, Classical Antiquity, 36 (1), 130-182.

Van Noorden, H. (2010). 'Hesiod's races and your own'. Socrates' Hesiodic project. In G. R. Boys-Stones and J. H. Haubold (Eds.), Plato and Hesiod (pp. 176-199). Oxford: Oxford University Press.

Walker, H. J. (1995). Theseus of Athens. Oxford: Oxford University Press.

White, St. (2000). Socrates at Colonus: A Hero for the Academy. In N. Smith and P. Woodruff (Eds.), Reason and Religion in Socratic Philosophy (pp. 151-175). Oxford: Oxford University Press.

Winnington-Ingram, R. P. (1980). Sophocles. An Interpretation. Cambridge University Press.

\section{Notes}

1 See Mikalson (2010), Ch.

2 Kearns (1989, pp. 44-63).

3 See Kron (1999, p. 62).

4 Paus. 1.15.3.

5 According to a tradition recorded by Plutarch, the men who fought in the Marathon saw the apparition of Theseus in the battlefield. See Plut. Thes. 35-36; Plut. Kim. 8; Paus. 1.17.6. On the story of the recovery and transference of his bones by Cimon from Skyros to Athens. See also Podlecki (1971, pp. 141-3).

6 The examination of this vexed issue lies beyond the scope of this article. See Nagy, 1979; Antonaccio (1994, pp. 389-410); and Bremmer (2007, p. 11) with further bibliography.

7 Ekroth (2002).

8 Azoulay (2014); Keesling (2017).

9 See Loraux (1981, pp. 39-42). On the heroization of the fifth-century Spartan general Brasidas, see Thucydides V. II. I.

10 See Parker (1996, p. 137).

11 See discussion in Blundell (1989).

12 See also Euripides, Heracleidai, 1032.

13 See Aristophanes Heroes, 4.

14 See, for example, Eisner (1982, pp. 106-18); Arieti (1986, pp. 129-42); Ahrensdorf (1995); Notomi (2011); Lampert (2021). Cf. Liebert (2020, pp. 442-66).

15 See Phaedo 85a-b and 85b7-9. In the Republic 4.427b1-c4 Socrates entrusts to Apollo the founding of sanctuaries and annual festivals. On Socrates' relation to Apollo and divination, see Morgan (2010, 63-81).

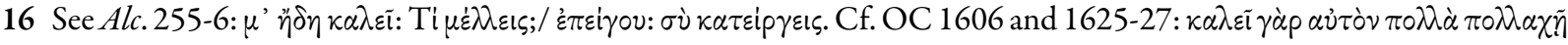

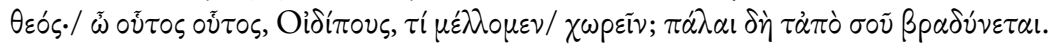

17 Phaedo 116a2-3; Alc. 158-62; OC 1595-59.

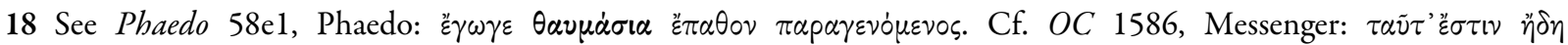
ка்

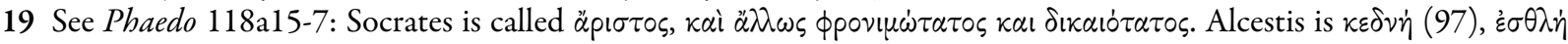

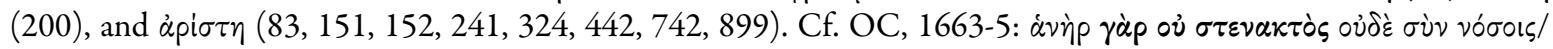

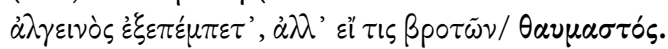

20 See Alc. 45-55 kaı 141-3.

21 In the following paragraphs I enhance some of the ideas which I argued in a previous article on Plato's Phaedo in Petraki (2015/2016, 127-162). 
22 See White (2000, 152-3). On hero-cult, see Farnell (1921), Nagy (1979, ch. 6), Kearns (1989), Walker (1995, p.9), Hagg (Ed.) (1999).

23 So White (2000, p. 153 and 163, n. 74). On the celebration of Plato and Socrates' birthdays see, Porph. Vita Plot. 2.

24 See Tilg (2004, p. 414); Edmunds (1981, pp. 221-38); Henrichs (1983, p. 100).

25 See Tilg (2004, pp. 411-14).

26 See Winnington-Ingram (1980, p. 345), Henrichs (1983, pp. 87-100), Tilg (2004, pp. 407-420), Edmunds (1996, pp. 138-42). Cf. Linforth (1951), Brown (1984, pp. 260-81). On Eumenides as deities of the dead, see Johnston (1999, pp. 250-89).

27 See Phaedo 66b7-c5.

28 See Ranasinghe (2000, pp. 51-105).

29 The transferal of the heroes' bones is insolubly related with the political aspect of hero-cult because as McCauley observes, "it is not the bones themselves which are important so much as the fact of their possession" (95). See discussion in McCauley (1999, pp. 85-98).

30 See $O C$ 1590-1605: Oedipus disappears into the depths of earth, in an area associated with Demeter, Persephone, and with other heroes' descent into Hades.

31 See Loraux (1995/2014, pp. 145-166).

32 Note that in Phaedo 89c-d, Plato also compares Socrates and Phaedo to the hero Heracles and his ally Iolaus. However, the 'labor' they must carry out successfully is to prove the immortality of the soul. This is insolubly associated with the introduction of the Forms. It is in this way that they can embark on a "second best sea-voyage" (99c-d).

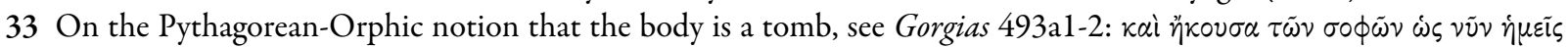

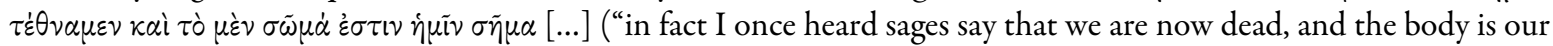
tomb $[. .] "$.

34 The reversal of the normal stages of burial is completed by the rejection of lamentation $(117 \mathrm{e})$. On the funerary customs, see Garland 1985.

35 According to Socrates, our real self is the soul which is not lost after death. See Phaedo 115c3 and 115d-116a.

36 I adopt this phrase from Edmunds 1981, who views in a comparative manner Sophocles' use of eidolon and phasma in $O C$.

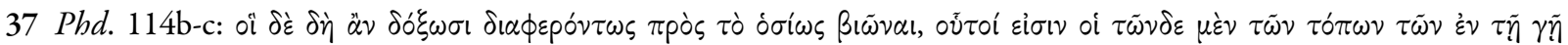

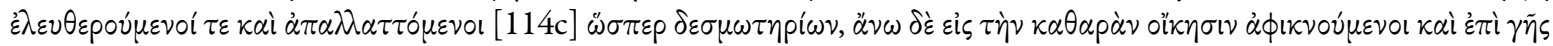

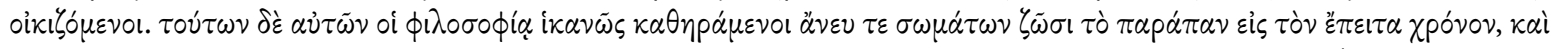

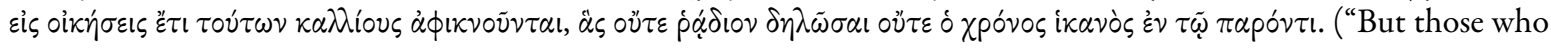
are found to have excelled in holy living are freed from these regions within the earth and are released as from prisons; they mount upward into their pure abode and dwell upon the earth. And of these, all who have duly purified themselves by philosophy live henceforth altogether without bodies, and pass to still more beautiful abodes which it is not easy to describe, nor have we now time enough.” Translation after H. N. Fowler)

38 The $\sigma \omega \tau \eta$ pi $\alpha$ is philosophical and comes from Socrates' presentation of the theory of Forms.

39 On Plato's views about the unjust condemnation of Socrates to death, see Phd. 118a15-7; Seventh Epistle, 324e; Second Epistle, $314 \mathrm{c} 4$.

40 Note that the rejection of conventional burial in the Phaedo, apart from its well-known Pythagorean-Orphic overtones, also has a religious and political dimension related to non-burial as a political punishment.

41 All translations of the Rep. are after Grube as revised by Reeve.

42 See also Book 9. 583b1-6, where an allusion is made to the Olympic games as part of the competition between the lives

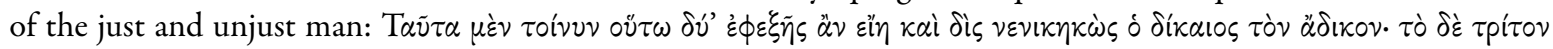

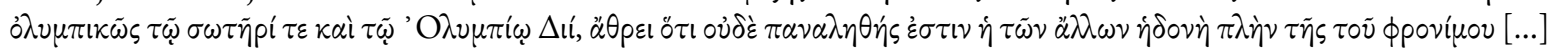
("These, then, are two proofs in a row, and the just person has defeated the unjust one in both. The third is dedicated in Olympic fashion to Olympian Zeus the Savior. Observe then that, apart from those of a knowledgeable person, the other pleasures are neither entirely true nor pure"). As Adam observes, the adverb ò $\nu \mu \pi \iota \kappa \tilde{\omega} \varsigma$ "is intended to suggest that the contest between justice and injustice is the greatest of all moral". An allusion is probably made to wrestling where the third throw was the decisive one in the contest between two athletes. The metaphor suggests that the just man wins after he has successfully defeated the unjust three times. For a similar metaphor, see also Phdr. 256b4-6.

43 See Republic. 473c11-e5.

44 See Iliad. 8. 162.

45 On Hesiod's gold, silver, bronze, heroic, and iron races, see Works and Days, 106-201.

46 Rep. $414 \mathrm{~b}-415 \mathrm{c}$.

47 Note that in the for the most part of Book 5 the division between guardians-epikouroi and guardians-philosophers is not fully drawn.

48 See, for example, $420 \mathrm{~b}-421 \mathrm{c}$. 
49 See Hall (1999, pp. 49-50, with n. 2).

50 See Pindar Ol. 5.8. Detailed discussion of Pindaric odes in Currie (2005, pp. 120-57); Day (2010, pp. 198-228); Kurke (1992, pp. 111-12) and Kurke (1993, pp. 149-50). Kurke (1991, pp. 163-94 and 207-8); Steiner (1998); and Steiner (2001).

51 See Fontenrose (1968, pp. 73-104); Kurke (1993, pp. 149-152); Gebhard and Dickie (1999, pp. 159-65). Currie (2005, pp. 120-124). Lunt (2009, pp. 375-392).

52 The anecdotal examples come mainly from late sources and are numerous. On Euthymos of Lokroi, see Paus. 6. 6. 7-11; Callim. Aitia, fr. 98-99 and Barron (1999, pp. $42-43$ with ns. 11 and 12), Currie (2002, pp. 24-44). The Spartans worshipped the wrestler Hipposthenes who won six Olympic crowns in the seventh century BCE (Paus. 3-13.9; 3.15.7). On Milo of Croton, see Diod. Sic. 12.9.5-6; Paus. 6.14.5-9; Strabo 6.1.12. On the pankratiast Polydamas (Olympic victor in 408 BC) See Diod. Sic. 9.14.2; Paus. 6.5.1, 4-9.

53 Other anecdotal examples of victorious athletes who became renowned for attaining heroic status and receiving cult honours include Theagenes from Thasos and Kleomedes of Astypalaea. See Keesling (2017).

54 Paus. 3-13.9; 3.15 .7

55 Diod. Sic. 12.9.5-6 (aĩ $10 v$ ); Paus. 6.14.5-9; Strabo 6.1.12.

56 See Diod. Sic. 9.14.2; Paus. 6.5.1, 4-9 for Polydamas' exploits; and Lucian, Parliament of the Gods 12. Paus. 6.6.4-10; Callimachus, Aetia fr. 98-99 (Pfeiffer); Pliny, Natural History 152; Aelian, Various Histories 8.18.

57 I discuss in detail Plato's use of sculptural imagery for the theoretical creation of the city-guardians so that they emulate the statues of athletic victors at Olympia in a separate study (reference omitted for blind peer-review). On statues of victors in Olympia, see Smith (2007, pp. 83-139).

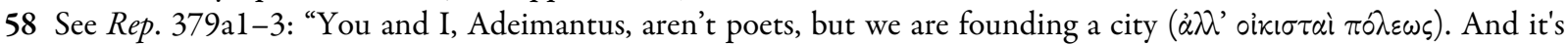

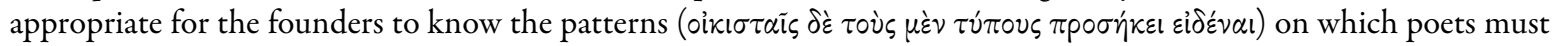

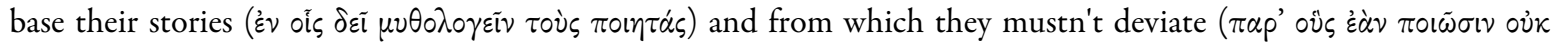
$\dot{\varepsilon} \pi \imath \tau \varepsilon \pi \tau \varepsilon \dot{\iota}($ ). But we aren't actually going to compose their poems for them."

59 Hdt. 5.47 attests the worship of a colonist named Philippos at Egesta in Sicily.

60 Malkin (1987, p. 2).

61 For a similar argument which links Socrates to the Olympic victors, see Apology 36d. In a moment of unsurpassed irony, Socrates proposes to the Athenian court that instead of punishment he should be granted privileges similar to those bestowed upon the Olympic victors. Socrates considers himself to be a benefactor of Athens far more superior "than any of you who has won a race at the Olympic games with a pair of horses or a four-in-hand. For he (the victor) makes you seem to be happy, whereas I make you happy in reality".

62 Laws 739a3-740c3. The comparison of the social and political constitutions of Magnesia to the political arrangements of the Republic is a controversial issue and lies outside the scope of this article. See, for example, discussion by Bobonich and Meadows (2020, rev. edition).

63 See Laws 728e-729a and passim.

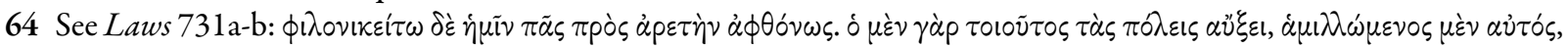

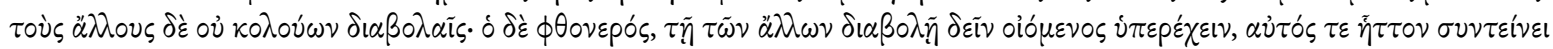

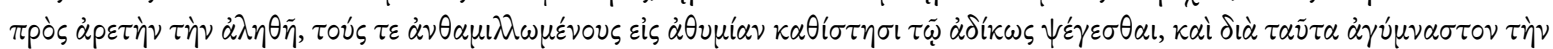

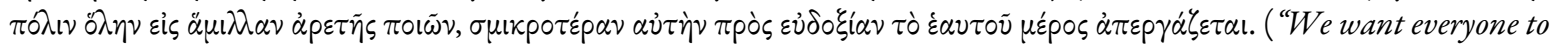
compete in the struggle for virtue in a generous spirit, because this is the way a man will be a credit to his state - by competing on his own account but refraining from fouling the chances of others by slander. The jealous man, who thinks he has to get the better of others by being rude about them, makes less effort himself to attain true virtue and discourages his competitors by unfair criticism. In this way he hinders the whole states' struggle to achieve virtue and diminishes its reputation, in so far it depends on him." Translation after Saunders slightly modified.) See discussion in Morgan (2013, pp. 265-294).

65 See Laws 947b-e.

66 See, for example, Mikalson (2010, Ch. 2).

67 The relation of daimonic nature with reincarnation has an Empedoclean background. See detailed discussion in Trepanier (2017, pp. 130-182).

68 See Nightingale (2021). 